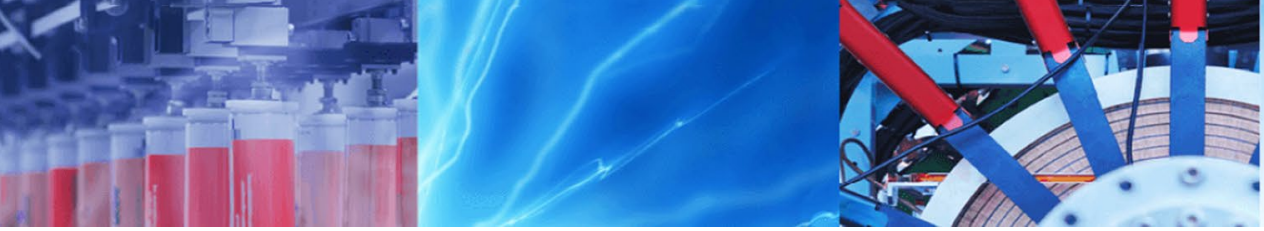

Research Article

\title{
Impact assessment of textile effluent on health and microbiota of agricultural soil in Bhagwanpur (Uttarakhand), India
}

\author{
Priya Pokhriya ${ }^{1} \cdot$ Richa Rajput $^{1} \cdot$ Prachi Nautiyal $^{1} \cdot$ Pooja Panwar $^{1} \cdot$ Deepshikha Pandey $^{1} \cdot$ Achlesh Daverey $^{1}$. \\ Ayyanadar Arunachalam ${ }^{2} \cdot$ Vijay Shridhar $^{1} \cdot$ Kusum Arunachalam $^{1}$
}

Received: 10 April 2020 / Accepted: 13 August 2020 / Published online: 20 August 2020

(c) Springer Nature Switzerland AG 2020

\begin{abstract}
Irrigation of agriculture field by untreated wastewater is a common practice in the water scarce regions in India. Increasing water crisis has forced the farmers to use untreated or partially treated wastewater in their agricultural fields. In this study, agricultural soil irrigated with textile effluent was examined at five different sites on the basis of proximity to the source and analysed for physicochemical and microbiological properties. Further, the co-relation of physicochemical properties with soil enzyme was also studied. The results revealed that soil respiration and microbial biomass carbon reduced by $53.8 \%$ and $65.9 \%$, respectively in the contaminated site as compared to control site, emphasizing the deleterious impact of effluent on the study site. Additionally, the bacterial population and dehydrogenase enzyme reduced by $41.6 \%$, and $71 \%$, respectively in the effluent affected soil as compared to the control site. Soil organic carbon showed a strong positive correlation $(p \leq 0.01)$ with soil enzyme activity. Other physicochemical and microbiological properties of the affected soil indicated negative impact on both soil quality and microbiota.
\end{abstract}

Keywords Microbial biomass carbon · Industrial effluent $\cdot$ Soil enzymatic activity · Urease $\cdot$ Wastewater reuse

\section{Introduction}

Increasing population and industrialization has led to an escalating demand for water globally. Indian economy that thrives majorly on agriculture utilizes 688 billion cubic meters of water, which accounts $85 \%$ of total water consumption [1]. However, with increased production targets and depleting water resources, use of untreated wastewater for agriculture purpose is prevalent in regions having water crisis. Although the use of wastewater for irrigation has potential benefit of nutrient reuse, it has adverse effects on the soil ecology and soil health $[2,3]$. Textile industry is one of the most prominent industries that utilizes and discharges huge volume of water. Textile effluent contains extreme concentrations of chemical oxygen demand (COD), biochemical oxygen demand (BOD),
$\mathrm{pH}$, dyes and heavy metals, along with other contaminants that are released into the nearby water bodies wherefrom it is used for irrigation of agricultural land $[4,5]$. The contaminants present in the effluent significantly affect the physical, chemical and biological properties of soil. Any change in physicochemical factors has a direct influence on the soil microbial diversity. The microbial populations in the wastewater irrigated soil shows reduction due to the presence of various organic compounds and heavy metals [6]. Soil irrigation with wastewater increases the soil conductivity due to its nutrient content and organic matter and soil salinity [7]. High nitrogen contents of wastewater tend to increase the organic and inorganic nitrogen pool [8]. Similar results have also been stated by Elfanssi et al. [9] who reported increase in conductivity, organic matter and $\mathrm{N}$ content in soil irrigated with raw wastewater.

Kusum Arunachalam, kusumdoon@gmail.com | 'School of Environment and Natural Resources, Doon University, Dehradun, Uttarakhand 248001, India. ${ }^{2}$ Indian Council of Agricultural Research, Krishi Bhawan, New Delhi 110001, India. 
In this context, soil enzyme activities provide a unique integrative biochemical assessment of soil and function as biological indicator of soil health [10]. Soil enzyme activity is mediated by enzymes present in the soil which are mainly contributed by the soil microorganisms. The enzymatic activities get significantly affected by factors such as soil $\mathrm{pH}$, temperature, moisture, organic matter content, soil depth, heavy metals and pesticides that further affects the enzymatic activity $[11,12]$. Among the different types of enzymes in soils, dehydrogenase, urease, and phosphatase are important in the transformation of different plant nutrients [13]. Dehydrogenase plays a vital role in maintaining soil fertility as well as its intracellular presence in all living microbial cells makes it the most important among all the enzymatic activity of soil [14, 15]. Phosphatase activity in the soil results in mobilization of organic phosphorus and is exhibited when there is a deficiency of phosphorus [16]. Similarly, for the transformation of urea present in the soil, urease an extracellular enzyme is secreted by the microbes for the breakdown of the urea-type substrate [17]. Besides enzymatic activity, soil microbial biomass carbon and microbial respiration are also indicators of soil quality and health $[18,19]$.

The effects of wastewater on growth of crop and soil has been discussed in a number of studies [20-22]. There is a dearth of information on affect of textile wastewater on soil physicochemical and biological properties especially in developing countries where untreated wastewater is often released into agricultural fields and used for irrigation purpose. In this study, we have examined soil samples from agriculture fields along the gradient of effluent release from the textile industry and analysed for physicochemical and microbiological properties and their co-relation with soil enzyme. Further, the study also assess the impact of discharged textile effluent on the microbiota and health of agricultural soil using enzymatic activity, soil respiration rate and microbial biomass carbon (MBC) as indices.

\section{Materials and methods}

\subsection{Study site}

The study site of this work is situated in the Bhagwanpur industrial area, Uttarakhand, India located at $29^{\circ} 57^{\prime} 53.4^{\prime \prime}$ $\mathrm{N}$ latitude and $77^{\circ} 46^{\prime} 36.8^{\prime \prime} \mathrm{E}$ longitude and above 293 asl. The average annual rainfall in the region is around $1174 \mathrm{~mm}$. Bhagwanpur experiences moderate to subtropical to humid climate with three distinct season's viz., summer, followed by rainy and winter seasons. In the summer, temperature varies from 27.2 to $40.6^{\circ} \mathrm{C}$. Temperature begins to fall in the mid of June with the commencement of monsoon season. During winter, temperature ranged $5.7^{\circ} \mathrm{C}$ and $11.9^{\circ} \mathrm{C}$. The weather parameters for the study period were recorded from the meteorological observatory located at National Institute of Hydrology; Roorkee located $25 \mathrm{~km}$ away from the experimental site. The mean daily maximum temperature ranged from 21.2 to $40.6^{\circ} \mathrm{C}$, whereas the mean daily minimum temperature ranged 5.7 to $27.1^{\circ} \mathrm{C}$. The site has normally relative humidity of $37-90 \%$ throughout the year. The wind speed during the study period varied between 0.35 to $2.65 \mathrm{~km} / \mathrm{h}$.

\subsection{Soil sampling}

Sampling was done near the textile industry in Bhagwanpur. The textile industry was established in 2009, discharging effluent at a rate of 480 kilo litre/day (data obtain from Uttar Pradesh Pollution Control Board) directly into the surrounded sampling area covering the fields for the purpose of irrigation. Control site was selected upstream of the textile mill where tube well water was used for irrigation. Five agriculture fields were selected along the gradient of effluent release from the industry. These fields were denoted with Site SI (nearest to textile effluent release) following SII, SIII, SIV and last Site SV (farthest from textile effluent release). From each site, six samples were collected randomly. Sampling was done in two seasons, i.e. winter dominated by wheat crop and summer dominated by rice. In each case, soil samples were taken from the top layer $(0-15 \mathrm{~cm})$ for performing the experiments. Total 72 samples ( 36 each season) were analysed including the samples from control site as shown in Fig. 1. Soil samples collected were sieved through a mesh size of $2 \mathrm{~mm}$ to remove the dead plant parts, stones and small insects and stored at $4{ }^{\circ} \mathrm{C}$ till further use.

\subsection{Textile effluent sampling and analysis}

The textile effluent sampling was conducted near the discharge point of textile industry. Five grab samples of textile effluent were collected in a duration of $24 \mathrm{~h}$ to make a composite sample. Similarly, the control water samples were collected from a tubewell which was located upstream away from the industrial area. The samples were pretreated with $5 \mathrm{ml} \mathrm{HNO} / 500 \mathrm{ml}$ effluent (except for BOD and $(\mathrm{CO})$ and transported to the laboratory in polyethylene bottles and stored at $4{ }^{\circ} \mathrm{C}$ in a refrigerator to prevent any changes in chemical characteristics until further analysis.

Physicochemical characteristics of textile effluent mentioned were assessed using standard protocols [23]. $\mathrm{pH}$ of the sample was measured using a glass electrode digital $\mathrm{pH}$ meter and electrical conductivity (EC) was measured using a digital electrical conductivity meter 

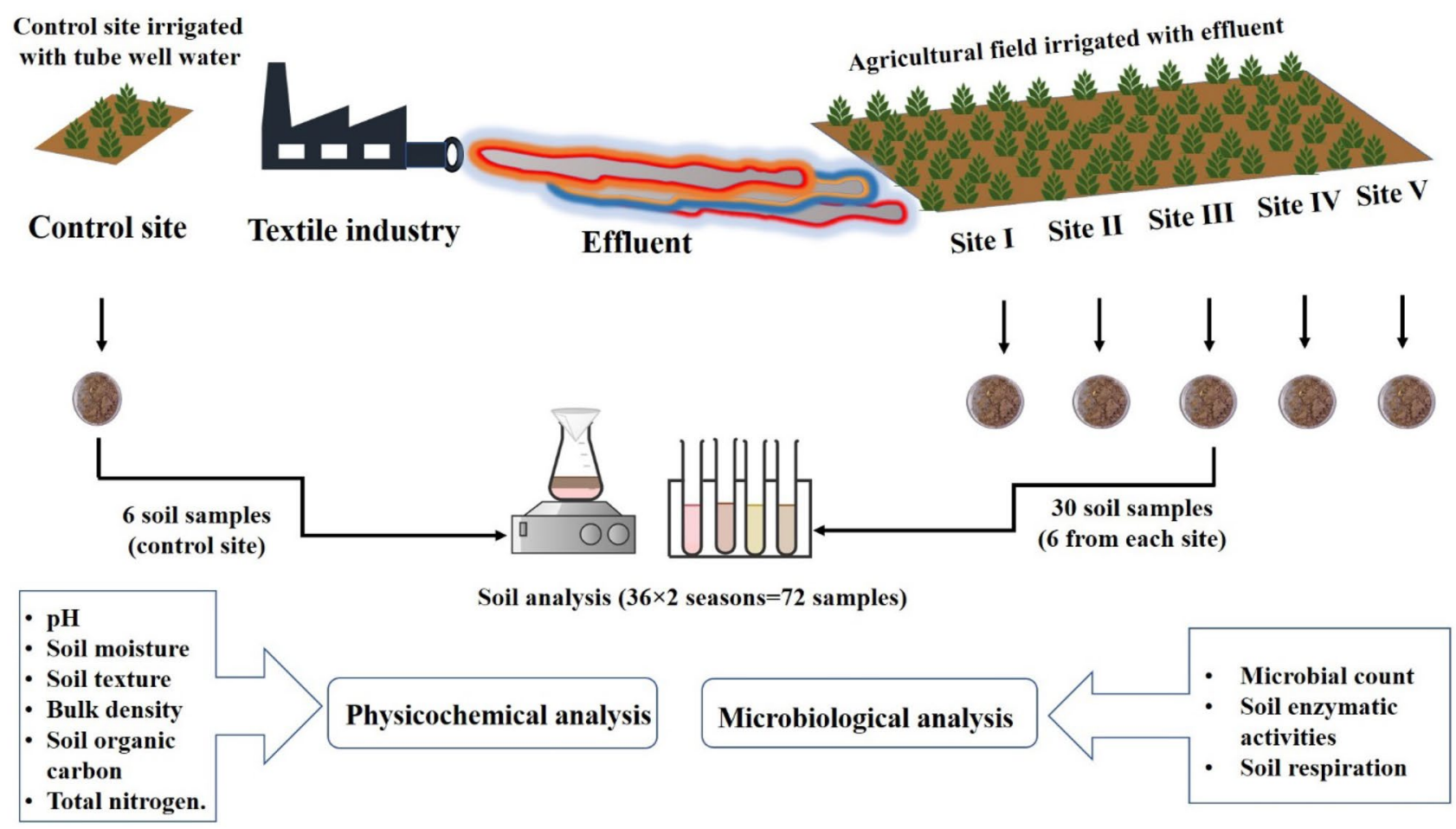

Fig. 1 Overview of the experimental design

within $24 \mathrm{~h}$ of sampling. All the chemicals used in the present study were of analytical grade and obtained from Merck and Sigma Aldrich.

\subsection{Analysis of soil properties}

Air-dried soil was used for the analysis of physicochemical properties like $\mathrm{pH}$, soil moisture, soil texture, bulk density, soil organic carbon percentage, soil carbon and total nitrogen. Soil pH (1:10 soil-water suspension) was determined by potentiometry [23]. Bulk density was determined by volumetric flask method [24]. Soil moisture was analysed by gravimetric method according to methods of analysis for soils of arid and semiarid regions [25], while international pipette method was used to estimate the soil texture [26]. Soil organic carbon was analysed by Walkley-Black wet oxidation method [27]. Soil organic matter was calculated by multiplying the soil organic carbon with a constant (1.724). Soil phosphorous was estimated using Olsen's method [28]. Available potassium in soil was estimated by flame photometer using ammonium acetate method [29]. Total carbon and nitrogen was analysed using CHNS-O analyser.

\subsection{Microbiological properties of soil}

Microbiological properties of the soil sample such as microbial count, soil enzymatic activities and soil respiration were determined. Soil microflora was enumerated by performing serial dilution plate count method [30]. The soil samples were subjected to serial dilution using $1 \mathrm{~g}$ of soil in $100 \mathrm{ml}$ of distilled water. Nutrient agar plate was used for bacterial count plate, actinomycetes isolation agar for actinomycetes and potato dextrose agar plate was used for fungi. Microbial population was counted in terms of Colony forming units per gram of soil (cfu/g).

Urease activity, was determined using phenol sodium hypochlorite method [31]. Dehydrogenase activity was determined using the procedure of Casida et al. [32]. Acid phosphatase and alkaline phosphatase were determined by method given by Tabatabai and Bremner [33]. Fumigaton-extraction method was used for the estimation of microbial biomass carbon (MBC) in the collected soil samples [34]. Appropriate blank was taken for each set of experiment.

Soil respiration was measured with portable soil respiration unit LI-8100A 4.0 automated soil $\mathrm{CO}_{2}$ flux system (LI-COR Biosciences, USA) connected to the PVC collar of 
$20 \mathrm{~cm}$ diameter and $10 \mathrm{~cm}$ height, which was inserted into the soil at the depth of $8 \mathrm{~cm}$ for acquiring the data. To avoid the effect of living plant materials it was removed from inside and around the area where collar was fixed. Three readings were taken at each of the six random sampling points (as described in Sect. 2.2) in all the sampling sites from I to $V$ and control site. Average of these three readings were recorded against the respective sampling point.

\subsection{Statistical analysis}

SPSS 16 software was used for analysing the data collected to determine the relationship between effluent discharged, on soil physicochemical properties, microbial count and microbial activity. Pearson's correlation was applied to assess the relation between various physicochemical and biological factors. Analysis of variance (ANOVA) was used to check the variation between microbial activity and sampling sites.

\section{Results and discussion}

\subsection{Characteristics of textile effluent}

The major problem associated with textile processing effluents is the presence of heavy metal ions, which arise from material (metal containing dye), used in the dyeing process [35]. Release of heavy metals from industries has resulted in the contamination of many agricultural sites and poses threat to the ecological system $[36,37]$. For effective effluent treatment and reclamation of polluted land, it is necessary that monitoring should be done carefully for better environmental protection means. In the present study, the analysed properties of the effluent used for irrigation purpose showed high values of different parameters as shown in Table 1. The $\mathrm{pH}$ value of 9.1 represents the alkaline nature of effluent. Also, the value obtained for biochemical oxygen demand (BOD) and chemical oxygen demand (COD) exceeded the CPCB (Central Pollution Control Board, Government of India) recommended value for wastewater for irrigation. The percent variation in biological oxygen demand of effluent was higher than the BOD of tubewell water. Average annual TSS (total suspended solids) and TDS (total dissolved solids) in the study were 2-4 times greater than the tubewell water. The results coincided with a study in Tirupur on the textile effluent, revealed that almost all the physicochemical parameters analysed were having higher values (BOD $407 \mathrm{mg} / \mathrm{l}$ to $662 \mathrm{mg} / \mathrm{l}, \mathrm{COD} 780 \mathrm{mg} / \mathrm{l}$ to $1460 \mathrm{mg} / \mathrm{l}, \mathrm{pH}$ 8-10), as compared to the recommended limits of CPCB.
Table 1 Physicochemical characteristics of textile effluent

\begin{tabular}{lcr}
\hline Parameters & Textile effluent & Tubewell (Control) \\
\hline $\mathrm{pH}$ & $9.1 \pm 0.11$ & $7.2 \pm 0.05$ \\
$\mathrm{EC}(\mu \mathrm{s} / \mathrm{cm})$ & $311.3 \pm 3.61$ & $130.7 \pm 1.59$ \\
$\mathrm{BOD}(\mathrm{mg} / \mathrm{l})$ & $135.0 \pm 4.51$ & $17.5 \pm 1.36$ \\
$\mathrm{DO}(\mathrm{mg} / \mathrm{l})$ & $0.7 \pm 0.04$ & $5.5 \pm 0.35$ \\
$\mathrm{COD}(\mathrm{mg} / \mathrm{l})$ & $461.7 \pm 11.42$ & $51.8 \pm 1.27$ \\
Alkalinity $(\mathrm{mg} / \mathrm{l})$ & $86.3 \pm 0.70$ & $24.1 \pm 1.53$ \\
Temperature $\left({ }^{\circ} \mathrm{C}\right)$ & $31.7 \pm 1.02$ & $28.3 \pm 1.68$ \\
$\mathrm{TSS}(\mathrm{mg} / \mathrm{l})$ & $230.8 \pm 5.54$ & $75.3 \pm 1.93$ \\
$\mathrm{TDS}(\mathrm{mg} / \mathrm{l})$ & $946.2 \pm 17.57$ & $193.3 \pm 6.50$ \\
$\mathrm{Na}(\mathrm{mg} / \mathrm{l})$ & $91.8 \pm 1.18$ & $13.2 \pm 1.35$ \\
$\mathrm{~K}(\mathrm{mg} / \mathrm{l})$ & $131.6 \pm 0.66$ & $17.1 \pm 2.46$ \\
$\mathrm{Mg}(\mathrm{mg} / \mathrm{l})$ & $35.1 \pm 3.59$ & $142.7 \pm 4.59$ \\
$\mathrm{Cl}(\mathrm{mg} / \mathrm{l})$ & $479.4 \pm 14.61$ & $198.3 \pm 6.64$ \\
\hline
\end{tabular}

\pm represents standard deviation

Therefore, suggesting its unsuitability to be discharged without any treatment in the nearby aquatic system [38].

\subsection{Physicochemical properties of textile effluent-affected agricultural soil}

The effluent-affected soil samples showed significant changes in all the parameters analysed as compared to the control site (Table 2). Increased soil alkalinity was observed in effluent-affected soil and the $\mathrm{pH}$ ranged from 7.7 to 8.4. On the other hand, soil from the control site exhibited $\mathrm{pH}$ 7.3. This slight shift in $\mathrm{pH}$ may be attributed to the continuous release of textile effluents containing bicarbonates and other alkaline chemicals $[39,40]$. Electrical conductivity (EC), another important parameter also exhibited similar trend. The EC of the soil irrigated with the effluent wastewater displayed higher values (164.8 $\mu \mathrm{s} /$ $\mathrm{cm}$ to $252.2 \mu \mathrm{s} / \mathrm{cm})$ than that of the control site $(100 \mu \mathrm{s} /$ $\mathrm{cm}$ ) (Table 2). A $20.6 \%$ reduction in EC in soils affected by the effluent was recorded when compared to the control site. The high concentration of iconic compounds present in the effluent may be attributed to the high EC content of the soil [41]. The bioavailability of metals from soil greatly depends on EC as increase in EC has been linked to enhancement of metal solubility [42].

Analogous results were reported by Arif et al. [43] studying effects of untreated textile wastewater on aridisol soil. In terms of texture, the percentage coarse sand was more in the affected site as compared to control, whereas percentage of fine sand was more in the control site soil than in the test site. The change in the soil texture of the present study could be attributed to change in soil density, enhanced total alkalinity, causing soil hardening and declined soil permeability [44]. The results 
Table 2 Physicochemical properties of effluent-affected agriculture soil

\begin{tabular}{|c|c|c|c|c|c|c|c|c|}
\hline Physicochemical Properties & Depth (cm) & Control & SI & SII & SIII & SIV & SV & $\%$ variation \\
\hline Bulk Density $\left(\mathrm{g} / \mathrm{cm}^{3}\right)$ & 15 & $1.46 \pm 0.4$ & $1.5 \pm .05$ & $1.3 \pm 0.05$ & $1.5 \pm 0.02$ & $1.4 \pm .02$ & $1.4 \pm .03$ & 1.44 \\
\hline $\mathrm{pH}$ & 15 & $7.3 \pm .12$ & $8.2 \pm .10$ & $8.4 \pm .10$ & $7.7 \pm .05$ & $8.3 \pm .06$ & $8.1 \pm .07$ & 11.6 \\
\hline Electri conductivity $(\mathrm{EC})(\mu \mathrm{s} / \mathrm{cm})$ & 15 & $100 \pm 0.76$ & $252.2 \pm 0.82$ & $240 \pm 1$ & $192.5 \pm 0.26$ & $195 \pm 0.54$ & $164.8 \pm 0.12$ & 20.6 \\
\hline Texture Class & 15 & Loam & Loam & Loam & Loam & Loam & Sandy loam & - \\
\hline Coarse Sand\% & 15 & $3.0 \pm 0.4$ & $3.0 \pm 0.26$ & $3.0 \pm 0.15$ & $3.0 \pm 0.42$ & $3.0 \pm 0.38$ & $2.0 \pm 0.2$ & 6.67 \\
\hline Fine sand $\%$ & 15 & $66.0 \pm 0.41$ & $70.0 \pm 0.57$ & $70.0 \pm 0.49$ & $68 \pm 0.51$ & $72 \pm 0.55$ & $75.0 \pm 0.32$ & 7.58 \\
\hline Silt \% & 15 & $16.0 \pm 0.06$ & $12.0 \pm 0.44$ & $12.0 \pm 0.23$ & $11.0 \pm 0.21$ & $10.5 \pm 0.21$ & $8.0 \pm 0.11$ & 33.13 \\
\hline Clay \% & 15 & $15.0 \pm 0.52$ & $15.0 \pm 0.11$ & $15.0 \pm 0.24$ & $15.0 \pm 0.81$ & $15.0 \pm 0.70$ & $15.0 \pm 0.48$ & 0.00 \\
\hline Moisture (\%) & 15 & $13.1 \pm 0.09$ & $9.3 \pm 0.10$ & $9.1 \pm 0.06$ & $13.2 \pm 0.10$ & $14.5 \pm 0.19$ & $10.0 \pm 0.12$ & 15.6 \\
\hline Total carbon (g/kg) & 15 & $10.6 \pm 0.21$ & $8 \pm 0.05$ & $8 \pm 0.11$ & $7 \pm 0.03$ & $6 \pm 0.16$ & $8 \pm 0.05$ & 28.9 \\
\hline Organic carbon (g/kg) & 15 & $7.8 \pm 0.06$ & $4.7 \pm 0.04$ & $4.6 \pm 0.05$ & $3.2 \pm 0.04$ & $4.1 \pm 0.08$ & $5.1 \pm 0.09$ & 44.5 \\
\hline Organic matter (g/kg) & 15 & $13 \pm 0.12$ & $8.5 \pm 0.04$ & $8.5 \pm 0.05$ & $5.1 \pm 0.05$ & $6.8 \pm 0.04$ & $8.5 \pm 0.05$ & 44.5 \\
\hline Total Nitrogen $(\mathrm{g} / \mathrm{kg})$ & 15 & $1.7 \pm 0.08$ & $1 \pm 0.06$ & $1 \pm 0.1$ & $1 \pm 0.08$ & $1 \pm 0.04$ & $1 \pm 0.07$ & 38.71 \\
\hline Available Phosphorous (mg/kg) & 15 & $24.80 \pm 0.06$ & $17.7 \pm 0.11$ & $17.0 \pm 0.05$ & $11.4 \pm 0.08$ & $8.6 \pm 0.10$ & $7.2 \pm 0.05$ & 50.05 \\
\hline Available potassium (mg/kg) & 15 & $114.1 \pm 1.18$ & $58.9 \pm 1.15$ & $58.5 \pm 0.09$ & $63.8 \pm 1.50$ & $96.7 \pm 2.03$ & $91.2 \pm 1.03$ & 35.27 \\
\hline
\end{tabular}

Values are the mean of 72 samples followed by \pm standard deviation

are corresponding with the study of Elwahed [45] who showed decreased clay content of soil due to dispersion by effluent application. This change in soil property affects the water-holding capacity of soil resulting in more compact soil with coarse texture, which could adversely affect the microbial population and its activity [46]. Both organic matter and organic carbon content of the affected sites were lesser as compared to the control site, although the variation within different sites was not very prominent. About $45 \%$ reduction in organic carbon content of soil at the effluent treated site was observed as compared to control site. Contrary to the present study, other studies have reported an increase in carbon content of agricultural soil on exposure of waste $[47,48]$. The effect of wastewater on soil physicochemical properties largely depends on the chemical constituents of the effluent [49], whereas few studies have reported the reduced organic matter in effluent treated soils caused by increased rate of mineralization in the presence of higher concentration of $\mathrm{N}, \mathrm{P}$, $\mathrm{K}$ and increased microbial activity in the water [50]. The decrease could also be attributed to reduced microbial biomass carbon in the effluent treated sites which is a substantial load of organic carbon [51]. Basic physicochemical properties of the effluent treated agricultural soil are shown in Table 2.

\subsection{Effects on microbiological properties of soil}

Microbial flora present in the soil is greatly influenced by the change in physicochemical properties of the soil. Microflora count obtained for contaminated site in both seasons (summer and winter) showed a decline in all three classes of microorganisms (bacterial, fungal and actinomycetes) as compared to the control site (Tables 3 and 4).

Table 3 Average of Microbiological properties of textile effluent effected agricultural soil in summer

\begin{tabular}{|c|c|c|c|c|c|c|}
\hline \multirow[t]{2}{*}{ Microbiological properties } & \multirow[t]{2}{*}{ Control } & \multicolumn{5}{|l|}{ Summer } \\
\hline & & $\overline{\mathrm{SI}}$ & SII & SIII & SIV & SV \\
\hline Bacterial population $\left(\times 10^{4} \mathrm{cfu} / \mathrm{g}\right)$ & $93.0 \pm 4.5$ & $40.3 \pm 2.8$ & $49.3 \pm 2.0$ & $44.0 \pm 3.4$ & $61.2 \pm 0.8$ & $77.2 \pm 1.7$ \\
\hline Fungal population $\left(\times 10^{3} \mathrm{cfu} / \mathrm{g}\right)$ & $8.67 \pm 1.7$ & $3.2 \pm 0.6$ & $7.4 \pm 0.8$ & $9.3 \pm 1.2$ & $10.7 \pm 0.5$ & $11.4 \pm 1.4$ \\
\hline Actinomycetes $\left(\times 10^{3} \mathrm{cfu} / \mathrm{g} / \mathrm{g}\right)$ & $2.33 \pm 0.6$ & $1.0 \pm 0.3$ & $2.3 \pm 0.9$ & $2.8 \pm 0.3$ & $1.2 \pm 0.3$ & $2.7 \pm 0.3$ \\
\hline Dehydrogenase ( $\mu \mathrm{g} / \mathrm{g}$ soil $/ \mathrm{h})$ & $2.051 \pm .07$ & $0.30 \pm .03$ & $0.4 \pm .03$ & $0.38 \pm 0.2$ & $0.44 \pm .03$ & $0.5 \pm 0.2$ \\
\hline Alkaline phosphatase ( $\mu \mathrm{g} \mathrm{pnp} / \mathrm{g}$ soil/hr) & $172.47 \pm 10.2$ & $132.1 \pm 2.4$ & $140.6 \pm 3.7$ & $132.7 \pm 2.4$ & $153.2 \pm 17.4$ & $143.1 \pm 18.3$ \\
\hline Urease $(\mu \mathrm{g} / \mathrm{g}$ soil $/ \mathrm{h})$ & $37.50 \pm 2.5$ & $25.5 \pm 0.34$ & $18.3 \pm 2.1$ & $20.8 \pm 1.8$ & $33.9 \pm 4.7$ & $29.6 \pm 5.1$ \\
\hline Soil respiration $\left(\mu \mathrm{mol} / \mathrm{m}^{2} / \mathrm{sec}\right)$ & $6.5 \pm 0.23$ & $1.6 \pm 0.05$ & $2.1 \pm 0.22$ & $3.79 \pm .01$ & $4.6 \pm 0.61$ & $5.3 \pm 0.54$ \\
\hline Microbial Biomass Carbon ( $\mu \mathrm{g} \mathrm{C/g}$ soil) & $421.6 \pm 22.7$ & $136.6 \pm 15.7$ & $149.5 \pm 0.9$ & $185.55 \pm 4.6$ & $218.3 \pm 22.5$ & $268.7 \pm 11.8$ \\
\hline
\end{tabular}

Values for each site is mean of 6 samples collected for summer season making total of 36 samples followed by \pm standard deviation 
Table 4 Average of microbiological properties of textile effluent affected agricultural soil in winter

\begin{tabular}{|c|c|c|c|c|c|c|}
\hline \multirow[t]{2}{*}{ Microbiological properties } & \multirow[t]{2}{*}{ Control } & \multicolumn{5}{|l|}{ Winter } \\
\hline & & $\mathrm{SI}$ & SII & SIII & SIV & SV \\
\hline Bacterial population $\left(\times 10^{4} \mathrm{cfu} / \mathrm{g}\right)$ & $94.2 \pm 4.1$ & $37.2 \pm 1.5$ & $43.8 \pm 9.8$ & $45.1 \pm 7.6$ & $72.0 \pm 7.2$ & $79.8 \pm 9.8$ \\
\hline Fungal population $\left(\times 10^{3} \mathrm{cfu} / \mathrm{g}\right)$ & $13.8 \pm 0.5$ & $4.9 \pm 0.5$ & $6.1 \pm 0.5$ & $5.5 \pm 0.8$ & $5.58 \pm 1.7$ & $7.17 \pm 0.5$ \\
\hline Actinomycetes $\left(\times 10^{3} \mathrm{cfu} / \mathrm{g} / \mathrm{g}\right)$ & $2.17 \pm 0.6$ & $1.2 \pm 0.0$ & $2.5 \pm 0.6$ & $2.33 \pm 0.3$ & $1.33 \pm 0.3$ & $2.33 \pm 0.3$ \\
\hline Dehydrogenase ( $\mu \mathrm{g} / \mathrm{g}$ soil/h) & $1.90 \pm .08$ & $0.21 \pm .02$ & $0.35 \pm .09$ & $0.75 \pm .01$ & $0.97 \pm .07$ & $1.24 \pm .01$ \\
\hline Alkaline phosphatase ( $\mu \mathrm{g} \mathrm{pnp} / \mathrm{g}$ soil/hr) & $97.76 \pm 0.8$ & $110.52 \pm 1.4$ & $136.8 \pm 1.6$ & $153.21 \pm 4.0$ & $140.63 \pm 1.7$ & $155.28 \pm 2.1$ \\
\hline Urease $(\mu \mathrm{g} / \mathrm{g}$ soil/h) & $56.41 \pm 7.9$ & $29.97 \pm 6.7$ & $33.1 \pm 4.4$ & $36.48 \pm 1.3$ & $36.72 \pm 0.7$ & $41.58 \pm 0.2$ \\
\hline Soil respiration $\left(\mu \mathrm{mol} / \mathrm{m}^{2} / \mathrm{sec}\right)$ & $8.24 \pm 0.3$ & $3.1 \pm 0.33$ & $4.4 \pm 0.17$ & $4.21 \pm 0.59$ & $4.4 \pm .06$ & $4.5 \pm 0.71$ \\
\hline Microbial Biomass Carbon ( $\mu \mathrm{g} \mathrm{C/g}$ soil) & $589.6 \pm 13.1$ & $165.4 \pm 0.5$ & $192.3 \pm 8.07$ & $184.70 \pm 6.1$ & $235.5 \pm 15.5$ & $268.2 \pm 52.5$ \\
\hline
\end{tabular}

Values for each site is mean of 6 samples collected for winter season making total of 36 samples followed by \pm standard deviation

Some studies have indicated similar account of decrease in microbial abundance and diversity after the application of industrial effluent $[52,53]$. The concentration of heavy metals may have stimulatory or inhibitory impact on the microbial population. Highly concentrated metals in soil show inhibitory effects on the microorganisms due to dysfunctional microbial processes such as decomposition, and soil respiration [54]. The decrease in microbial count could also be linked with decrease in the concentration of organic carbon required for sustaining microbial growth [55]. However, no specific trend was observed for microbial count at different sites. The correlation coefficient showed significantly positive relation $(p \leq 0.05)$ between the organic carbon content and microbial count in the affected soil (Table 5). Soil microorganisms are very sensitive towards environmental changes. The decrease in microbial population from textile wastewater may be attributed to the heavy metals present in the wastewater. Under heavy metal stress, there is inadequate amount of substrate available for the microbes due to lower mineralization of the organic matter [56].

Soil enzyme activities are commonly influenced by physicochemical properties of soil [57]. Among the data obtained for the two seasons, the dehydrogenase activity in the soil sample collected in the summer showed concentration ranging from 0.30 to $0.52 \mu \mathrm{g} / \mathrm{g}$ soil/h whereas it varied from 0.21 to $1.24 \mu \mathrm{g} / \mathrm{g}$ soil/h in winter season, as compared to the control site where the value obtained is $2.0 \mu \mathrm{g} / \mathrm{g}$ soil/h (Tables 3 and 4). Also, slight increasing trend has been observed in the activity from site I to site $\mathrm{V}$. Decrease in dehydrogenase could be the result of the hindrance of the active site of the enzymes by the trace metal ions [58]. This is in contrast to the results obtained by Roohi et al. [59] who observed an increased dehydrogenase activity in textile effluent irrigated soil probably because of the high organic matter content. Also, when compared the activity between different sites slight increasing trend has been observed in the activity from site I to site V. The one-way ANOVA (Table 6) between different sites along gradient showed significant change in the dehydrogenase activity among different sites $(p \leq 0.05)$.

Urease enzyme, an important soil health indicator representing the available nitrogen concentration of the soil was found to be slightly less than the control site. Urease activity ranged from 25.5 to $29.6 \mu \mathrm{g} / \mathrm{g} \mathrm{soil} / \mathrm{h}$ in summer and in $29.97 \mu \mathrm{g} / \mathrm{g}$ soil $/ \mathrm{h}$ to $41.58 \mu \mathrm{g} / \mathrm{g}$ soil $/ \mathrm{h}$ in winter as compared to $37.55 \mu \mathrm{g} / \mathrm{g}$ soil $/ \mathrm{h}$ and $56.415 \mu \mathrm{g} / \mathrm{g}$ soil $/ \mathrm{h}$, respectively in the control site (Tables 3 and 4). Between different sites the change in urease activity was found nonsignificant $(0.496, p \leq 0.05)$ as represented by one-way ANOVA (Table 6). About $45 \%$ reduction in urease activity was observed between the unaffected and affected soil. Reduced urease activity could be corroborated with lower values of total nitrogen content in the soil of all selected sites despite receiving discharge from the textile mill [60]. There is a strong relationship between urease and dehydrogenase enzymatic activities as evident from the correlation coefficient obtained $(0.673, p \leq 0.01)$, in the present investigation (Table 5) which is in accordance with literature report [43].

Phosphatase enzyme has critical role in hydrolysis of phosphate bonds and release of phosphorous in available form to be taken up by plants or microorganisms [15]. Alkaline phosphatase activity decreased in the affected sites as compared to the control site. Data showed an increasing trend in activity with the increasing distance from the source of effluent release in both the seasons (132.1 to $143.1 \mathrm{pnp}$ released/g soil/h in summer and 110.52 to $155.28 \mathrm{pnp}$ released/g soil/h in winter) (Tables 3 and 4), similar to the results reported by [61]. However, the change was nonsignificant with the increase in distance, according to one-way ANOVA (Table 6). The overall low activity of alkaline phosphatase in textile mill effluent irrigated soil can be attributed to the lower bacterial count in the soil as compared to the control site which is also reflected in the correlation of bacterial count with alkaline 


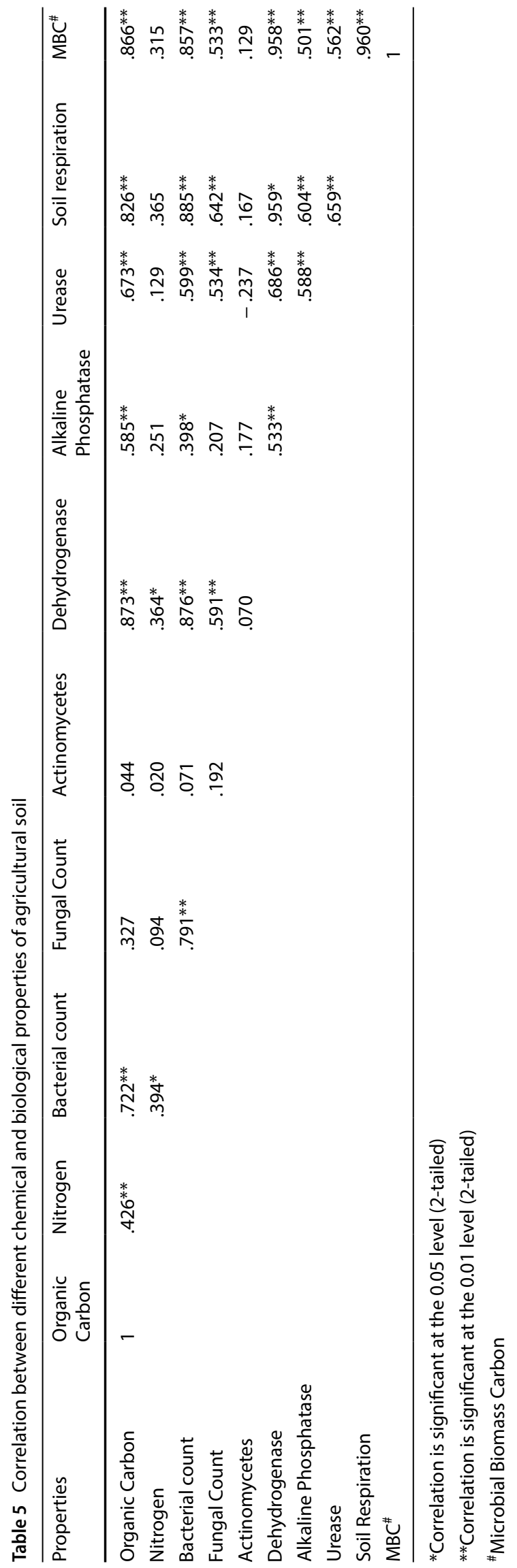

phosphatase $(0.398, p \leq 0.05)$ (Table 5$)$. A $41.6 \%$ reduction in bacterial population was observed in the effluent effected soil as compared to the control site.

Among all the selected study sites, MBC varied along the sites during the study period. The MBC is an integral part of biogeochemical cycle of nutritive elements [62]. The MBC in control site was significantly higher $(589.6 \mu \mathrm{g}$ $\mathrm{C} / \mathrm{g}$ soil) than the contaminated sites although its concentration showed an increasing trend with increasing distance from the point of origin of effluent (SI-SV) (Tables 3 and 4). Table 6 showed significance in change in the MBC among the different sites. The soil near the source of effluent input showed MBC of $136.6 \mu \mathrm{g} \mathrm{C} / \mathrm{g}$ soil and at the most distant point its values was $268.7 \mu \mathrm{g} \mathrm{C} / \mathrm{g}$ soil. The MBC in winter also showed a similar trend as it ranged from 165.4 soil to $268.2 \mu \mathrm{g} \mathrm{C} / \mathrm{g}$ soil. Correlation coefficient applied in the study showed that there is a positive correlation between MBC and organic carbon $(r=0.873, p \leq 0.001)$ (Table 5). Decrease in the MBC has been recorded in the effluent affected soil as compared to the control site. For instance, a reduction of $65.9 \%$ in MBC in soils affected by effluent was recorded when compared with the control site. The decrease in MBC could be due to accumulation of contaminants present in the effluent [63]. So, there may be a conjoint effect of heavy metals, high $\mathrm{pH}$ and high salt concentration which influence the activity rate of microflora and thus influencing the $M B C$ content in the soil. Heavy metal-induced microbial carbon inhibition was also supported by Chen et al. [64].

Soil respiration is also considered as an effective indicator of soil health as it indicates the soil microbial activity, organic matter percentage in the soil and its decomposition [65]. A trend similar to MBC was observed for soil respiration along different sites. Table 6 shows the significant $(0.00, p \leq 0.05)$ change in soil respiration as the distance between discharge point of effluent to agricultural fields increased. Respiration rate varied between 1.6 and $5.3 \mu \mathrm{mol} / \mathrm{m}^{2} / \mathrm{s}$ in summer, while in the winter season, the rate of soil respiration increases 3.1 to $4.5 \mu \mathrm{mol} / \mathrm{m}^{2} / \mathrm{s}$ (Tables 3 and 4). The soil respiration rate of the control site was observed to be $6.5 \mu \mathrm{mol} / \mathrm{m}^{2} / \mathrm{s}$ in summer and $8.24 \mu \mathrm{mol} / \mathrm{m}^{2} / \mathrm{s}$ in winter. Overall, $53 \%$ reduction in soil respiration was recorded in the affected site as compared to the control site of the present study. The decrease in soil respiration in sites closer to the effluent source $(\mathrm{SI})$ may be due to heavy load of contaminants which interferes in microbial activity [66]. Similarly, a study on soil treated with cassava effluent showed a reduction in the substrate availability due to heavy metals resulting in decreased soil respiration on increasing the concentration of effluent [67]. However, no correlation between the contamination level and the reduction in soil respiration has also been reported in the literature [68]. 
Table 6. One-way ANOVA between Sites (Independent factor) and Bacterial count, fungal count, enzyme activity, soil respiration and microbial biomass carbon (Dependant factors)

\begin{tabular}{|c|c|c|c|c|c|c|}
\hline & Source of variation & Sum of Squares & $d f$ & Mean Square & $F$ & Sig \\
\hline \multirow[t]{3}{*}{ BacterialCount } & Between Groups & 7142.688 & 4 & 1785.67 & 25.566 & .0001 \\
\hline & Within Groups & 2444.631 & 55 & 69.847 & & \\
\hline & Total & 9587.320 & 59 & & & \\
\hline \multirow[t]{3}{*}{ FungalCount } & Between Groups & 134.462 & 4 & 33.615 & 1.093 & .375 \\
\hline & Within Groups & 1076.175 & 55 & 30.748 & & \\
\hline & Total & 1210.637 & 59 & & & \\
\hline \multirow[t]{3}{*}{ Actinomycetes } & Between Groups & 17.183 & 4 & 4.296 & 3.203 & .024 \\
\hline & Within Groups & 46.949 & 55 & 1.341 & & \\
\hline & Total & 64.132 & 59 & & & \\
\hline \multirow[t]{3}{*}{ Dehydrogenase } & Between Groups & 1.492 & 4 & .373 & 5.620 & .001 \\
\hline & Within Groups & 2.322 & 55 & .066 & & \\
\hline & Total & 3.814 & 59 & & & \\
\hline \multirow[t]{3}{*}{ Alkaline phosphatase } & Between Groups & 5684.727 & 4 & 1421.182 & 2.167 & .093 \\
\hline & Within Groups & $22,954.020$ & 55 & 655.829 & & \\
\hline & Total & $28,638.747$ & 59 & & & \\
\hline \multirow[t]{3}{*}{ Urease } & Between Groups & 442.459 & 4 & 110.615 & .862 & .496 \\
\hline & Within Groups & 4490.315 & 55 & 128.295 & & \\
\hline & Total & 4932.774 & 59 & & & \\
\hline \multirow[t]{3}{*}{ Soil respiration } & Between Groups & 33.024 & 4 & 8.256 & 12.328 & .000 \\
\hline & Within Groups & 23.439 & 55 & 670 & & \\
\hline & Total & 56.462 & 59 & & & \\
\hline \multirow[t]{3}{*}{ Microbial biomass carbon } & Between Groups & $71,038.010$ & 4 & $17,759.502$ & 28.225 & .0001 \\
\hline & Within Groups & $22,022.250$ & 55 & 629.207 & & \\
\hline & Total & $117,817.389$ & 59 & & & \\
\hline
\end{tabular}

Significant at $p \leq 0.05$
Statistically analysed data also showed the enzymatic activity is directly correlated with the organic carbon content, bacterial, fungal count, soil respiration and MBC. The correlation coefficient (Table 5) between the bacterial count, dehydrogenase and fungal showed a positive significant relationship $(p \leq 0.001)$. Organic carbon showed a strong positive correlation (at $p \leq 0.01$ ) with dehydrogenase, alkaline phosphatase and urease activity, while total nitrogen had less influence on these activities.

\section{Conclusion}

The present study concludes that irrigating agricultural fields with textile effluent have significant impact on the chemical and biochemical activities of soil. Overall, the effluent treated soils have more negative impact as compared to the control site which may be due to the presence of contaminants like heavy metals in effluent discharged on experimental site. Moreover, the proximity of sites to the effluent source also had a prominent effect with sites closer to the effluent source showing declined soil properties as compared to those located at a distant from the industry perhaps due to the dilution in the contamination with the increasing distance. Soil enzymes which are indicative of soil health were also altered with the dehydrogenase activity showing significant decline, while variation observed for urease and alkaline phosphatase was not significant. The use of wastewater in irrigation for long run can deteriorate soil and therefore, the practice of irrigation from textile mill wastewater without proper treatment and amendments in the wastewater should be discouraged.

Further studies should be carried out to check the bioaccumulation of heavy metals in the food chain by analysing heavy metal concentration in agriculture soil and crop irrigated by wastewater. As well as heavy metals in groundwater should be taken into consideration because of prolonged irrigation there may be leaching of the metals into groundwater level.

\section{Compliance with ethical standards}

Conflict of interest All the authors declared that they have no conflict of interest. 


\section{References}

1. Scheierling SM, Tréguer DO (2018) Beyond crop per drop: assessing agricultural water productivity and efficiency in a maturing water economy. The World Bank, Washington, D.C.

2. Christou A, Agüera A, Bayona JM et al (2017) The potential implications of reclaimed wastewater reuse for irrigation on the agricultural environment: the knowns and unknowns of the fate of antibiotics and antibiotic resistant bacteria and resistance genes-a review. Water Res 123:448-467

3. Valipour M, Singh VP (2016) Global experiences on wastewater irrigation: challenges and prospects Balanced urban development: options and strategies for liveable cities. Springer, Cham, pp 289-327

4. Singare PU, Dhabarde SS (2014) Pollution due to textile industries along Dombivali Industrial Belt of Mumbai, India. Int Lett Chem Phys Astron 3:24-31

5. Morshed MN, Al Azad S, Alam MAM et al (2016) An instigation to green manufacturing: characterization and analytical analysis of textile wastewater for physico-chemical and organic pollution indicators. Am J Environ Sci Technol 1:11-21

6. Khan S, Malik A (2018) Toxicity evaluation of textile effluents and role of native soil bacterium in biodegradation of a textile dye. Environ Sci Pollut Res 25(5):4446-4458

7. Yalçuk A, Zenginbal H, Okcu GD (2019) The effect of irrigation by textile wastewater on the growth of MM106 Apple Sapling and Soil. Int J Environ Pollut Environ Model 2(2):68-79

8. Roohi M, Riaz M, Arif MS, Shahzad SM et al (2017) Low C/N ratio raw textile wastewater reduced labile $C$ and enhanced organic-inorganic $\mathrm{N}$ and enzymatic activities in a semiarid alkaline soil. Environ Sci Pollut Res 24(4):3456-3469

9. Elfanssi S, Ouazzani N, Mandi L (2018) Soil properties and agro-physiological responses of alfalfa (Medicago sativa L.) irrigated by treated domestic wastewater. Agric Water Manag 202:231-240

10. Igalavithana AD, Farooq M, Kim K-H et al (2017) Determining soil quality in urban agricultural regions by soil enzyme-based index. Environ Geochem Health 39:1531-1544

11. Cao H, Chen R, Wang L et al (2016) Soil pH, total phosphorus, climate and distance are the major factors influencing microbial activity at a regional spatial scale. Sci Rep 6:1-10

12. Acosta-Martinez V, Cano A, Johnson J (2018) Simultaneous determination of multiple soil enzyme activities for soil health-biogeochemical indices. Appl soil Ecol 126:121-128

13. Adetunji AT, Lewu FB, Mulidzi R, Ncube B (2017) The biological activities of $\beta$-glucosidase, phosphatase and urease as soil quality indicators: a review. J Soil Sci Plant Nutr 17:794-807

14. Abdul MM, Yalwa TR, Yusuf SA (2018) Evaluation of some soil properties on dehydrogenase activity in River Getsi Kano State, Nigeria. Malaysian J Appl Sci 3:34-41

15. Sherene T (2017) Role of soil enzymes in nutrient transformation: a review. Bio Bull 3:109-131

16. Kumari JA, Rao PC, Padmaja G, Madhavi M (2017) Effect of physico-chemical properties on soil enzyme acid phosphatase activity of some soils in vegetable growing soils of Ranga Reddy District of Telangana State, India. Int J Curr Microbiol Appl Sci 6:3496-3503

17. Kravkaz Kuscu IS, Cetin M, Yigit N et al (2018) Relationship between enzyme activity (Urease-Catalase) and nutrient element in soil use. Polish J Environ Stud 27:2107

18. Wani AS, Wani MA, Sheikh AA, Chand S (2017) Microbiologicalindicators with potential for evaluating soil quality. Int J Curr Microbiol Appl Sci 6:831-839
19. Bakhshandeh E, Francaviglia R, Renzi G (2019) A cost and timeeffective method to evaluate soil microbial respiration for soil quality assessment. Appl Soil Ecol 140:121-125

20. Biswas SK, Mojid MA (2018) Changes in soil properties in response to irrigation of potato by urban wastewater. Commun in Soil Sci Plant Anal 49(7):828-839

21. Elcossy SA, Abbas MH, Farid IM, Beheiry GG, Abou Yuossef MF, Abbas HH, Abdelhafez AA, Mohamed I (2020) Dynamics of soil organic carbon in Typic Torripsamment soils irrigated with raw effluent sewage water. Environ Sci Pollut Res 27(8):8188-98

22. Saha JK, Selladurai R, Coumar MV et al (2017) Impacts of soil pollution and their assessment. In: Saha JK, Selladurai R, Coumar MV, et al. (eds) Soil pollution-an emerging threat to agriculture. Springer, Berlin, pp 37-73

23. Apha W (2006) Awwa stand methods exam water wastewater, 19th edn. American Public Health Association, Washingt DC

24. Waring SA, Bremner JM (1964) Ammonium production in soil under waterlogged conditions as an index of nitrogen availability. Nature 201:951-952

25. Bashour II, Sayegh AH (2007) Methods of analysis for soils of arid and semi-arid regions. Food and Agriculture Organization of the United Nations Rome, Italy

26. Piper CS (2017) Soil and plant analysis. Scientific Publishers, Rajasthan

27. Nelson DW, Sommer LE (1982) Total carbon, organic carbon and organic matter. In: Pager AL, Hiller RH, Keenay DR (eds) Method of soil analysis, Part II. American Society of Agron, Agron, pp 477-539

28. Olsen SR (1954) Estimation of available phosphorus in soils by extraction with sodium bicarbonate. US Department of Agriculture

29. Black CA, Evans DD, White JL, Ensminger LE, Clarke FE (1965) Methods of soil analysis. American Society of Agronomy, part I. Madison Wisconsin, pp 1-770

30. Jenkinson DS, Powlson DS (1976) The effects of biocidal treatments on metabolism in soil-V: a method for measuring soil biomass. Soil Biol Biochem 8:209-213

31. Fawcett JK, Je S (1960) A rapid and precise method for the determination of urea. J Clin Pathol 13:156-159

32. Casida LE Jr, Klein DA, Santoro T (1964) Soil dehydrogenase activity. Soil Sci 98:371-376

33. Tabatabai MA, Bremner JM (1969) Use of p-nitrophenyl phosphate for assay of soil phosphatase activity. Soil Biol Biochem 1:301-307

34. Vance ED, Brookes PC, Jenkinson DS (1987) Microbial biomass measurements in forest soils: the use of the chloroform fumigation-incubation method in strongly acid soils. Soil Biol Biochem 19:697-702

35. Joshi VJ, Santani DD (2012) Physicochemical characterization and heavy metal concentration in effluent of textile industry. Univ J Environ Res Technol 2(2):93-96

36. Dermont G, Bergeron M, Mercier G, RicherLaflèche M (2008) Soil washing for metal removel: a review of physical/chemical technologies and field applications. J Hazard Mate 152(1):1-31

37. Wei C, Wang C, Yang L (2008) Characterizing spatial distribution and sources of heavy metals in the soils from miningsmelting activities in Shuikoushan Hunan Province, China. Int J Environ Sci 21:1230-1236

38. Manikandan P, Palanisamy PN, Baskar R, Sivakumar P, Sakthisharmila P (2015) Physico chemical analysis of textile industrial effluents from Tirupur City. Int adv res j sci eng technol 4:93-104

39. Abegunrin TP, Awe GO, Idowu DO, Adejumobi MA (2016) Impact of wastewater irrigation on soil physico-chemical properties, growth and water use pattern of two indigenous vegetables in southwest Nigeria. CATENA 139:167-178 
40. Sathiyaraj G, Ravindran KC, Malik ZH (2017) Physico-chemical characteristics of textile effluent collected from Erode, Pallipalayam and Bhavani polluted regions, Tamilnadu, India. J Ecobiotechnol 9:1-4

41. Singh R, Glick BR, Rathore D (2020) Role of textile effluent fertilization with biosurfactant to sustain soil quality and nutrient availability. J Environ Manage 268:110664

42. Chaoua S, Boussaa S, Gharmali AE, Boumezzough A (2019) Impact of irrigation with wastewater on accumulation of heavy metals in soil and crops in the region of Marrakech in Morocco. J Saudi Soc 18:429-436

43. Arif MS, Riaz M, Shahzad SM et al (2016) Contrasting effects of untreated textile wastewater onto the soil available nitrogenphosphorus and enzymatic activities in aridisol. Environ Monit Assess 188:102

44. Li F, Huang G, Ding Y, Peng C (2006) Effects of soil alkalinity, gypsum application, and filtration disposal on hydraulic conductivity under irrigation with domestic effluent water. Trans Chin Soc Agric Eng 22:48-52

45. Elwahed MSA (2018) Influence of long-term wastewater irrigation on soil quality and its spatial distribution. Ann Agric Sci 63:191-199

46. Siebe C, Fischer WR (1996) Effect of long-term irrigation with untreated sewage effluents on soil properties and heavy metal adsorption of leptosols and vertisols in Central Mexico. J Plant Nutr Soil Sc 159:357-364

47. Chaoua S, Boussaa S, Gharmali AE, Boumezzough A (2019) Impact of irrigation with wastewater on accumulation of heavy metals in soil and crops in the region of Marrakech in Morocco. J Saudi Soc Agric Sci 18:429-436

48. Mojid MA, Hossain A, Wyseure GCL (2019) Impacts of municipal wastewater on the transport characteristics of reactive solutes through agricultural soils. Commun Soil Sci Plant Anal 50:1199-1213

49. Razzaghi S, Khodaverdiloo H, Dashtaki SG (2016) Effects of longterm wastewater irrigation on soil physical properties and performance of selected infiltration models in a semi-arid region. Hydrolog Sci J 61:1778-1790

50. Oliveira PCP, Gloaguen TV, Gonçalves RAB, Santos DL, Couto CF (2016) Soil Chemistry after irrigation with treated wastewater in semiarid climate. Rev Bras Cienc Solo 40:e0140664

51. Fließbach A, Martens R, Reber HH (1994) Soil microbial biomass and microbial activity in soils treated with heavy metal contaminated sewage sludge. Soil Biol Biochem 26:1201-1205

52. Li D, Jiang X, Wang J, Wang K, Zheng B (2017) Effect of sewage and industrial effluents on bacterial and archaeal communities of creek sediments in the Taihu Basin. Water 9:373

53. Lenart A, Wolny-Koładka K (2013) The effect of heavy metal concentration and soil $\mathrm{pH}$ on the abundance of selected microbial groups within ArcelorMittal Poland steelworks in Cracow. B Environ Contam Tox 90:85-90

54. Tyler G (1974) Heavy metal pollution and soil enzymatic activity. Plant Soil 41:303-311

55. Liu M, Sui $X$, Hu Y, Feng F (2019) Microbial community structure and the relationship with soil carbon and nitrogen in an original
Korean pine forest of Changbai Mountain China. BMC Microbiol $19: 218$

56. Akmal M, Jianming $X$, Zhaojun L, Haizhen W, Huaiying $Y(2005)$ Effects of lead and cadmium nitrate on biomass and substrate utilization pattern of soil microbial communities. Chemosphere 60:508-514

57. Bueis T, Turrión MB, Bravo F et al (2018) Factors determining enzyme activities in soils under Pinus halepensis and Pinus sylvestris plantations in Spain: a basis for establishing sustainable forest management strategies. Ann For Sci 75:34

58. Mikanova O (2006) Effects of heavy metals on some soil biological parameters. J Geochem Explor 88:220-223

59. Roohi M, Riaz M, Arif MS et al (2016) Varied effects of untreated textile wastewater onto soil carbon mineralization and associated biochemical properties of a dryland agricultural soil. J Environ Manage 183:530-540

60. Zhang $T$, Wan S, Kang Y, Feng $H$ (2014) Urease activity and its relationships to soil physiochemical properties in a highly saline-sodic soil. J Soil Sci Plant Nutr 14:304-315

61. Kumawat S, Yadav B, Majumdar S (2017) Effect of municipal sewage on soil biological properties in the vicinity of Jaipur City of Eastern Rajasthan, India. Int J Curr Microbiol App Sci 6:1683-1689

62. Trivedi P, Wallenstein MD, Delgado-Baquerizo M, Singh BK (2018) Microbial modulators and mechanisms of soil carbon storage. In: Singh B (ed) soil carbon storage. Elsevier, Amsterdam, pp 73-115

63. Xu Y, Seshadri B, Bolan N et al (2019) Microbial functional diversity and carbon use feedback in soils as affected by heavy metals. Environ Int 125:478-488

64. Chen J, He F, Zhang X et al (2014) Heavy metal pollution decreases microbial abundance, diversity and activity within particle-size fractions of a paddy soil. FEMS Microbiol Ecol 87:164-181

65. Xu M, Shang $H$ (2016) Contribution of soil respiration to the global carbon equation. J Plant Physiol 203:16-28

66. Kaplan H, Ratering S, Hanauer T et al (2014) Impact of trace metal contamination and in situ remediation on microbial diversity and respiratory activity of heavily polluted Kastanozems. Biol Fertil soils 50:735-744

67. Igbinosa EO (2015) Effect of cassava mill effluent on biological activity of soil microbial community. Environ Monit Assess $187: 418$

68. Zornoza R, Acosta JA, Martínez-Martínez S et al (2015) Main factors controlling microbial community structure and function after reclamation of a tailing pond with aided phytostabilization. Geoderma 245:1-10

Publisher's Note Springer Nature remains neutral with regard to jurisdictional claims in published maps and institutional affiliations. 